\title{
Gangguan Tidur pada Pasien Stroke Fase Akut
}

\author{
Lisda Amalia \\ Departemen Neurologi Fakultas Kedokteran Universitas Padjadjaran-RSUP dr. Hasan Sadikin Bandung
}

\begin{abstract}
Abstrak
Stroke adalah suatu kondisi ketika seseorang terkena defisit neurologis secara tiba-tiba yang disebabkan oleh adanya gangguan pada pembuluh darah otak. Sekitar 21-77\% dari pasien stroke memiliki gangguan tidur yang terjadi setelah stroke. Siklus tidur diatur oleh otak dan stroke dapat menyebabkan gangguan tidur karena kelainan yang dapat terjadi pada struktur otak yang mengatur tidur. Post Stroke Sleep Disoder (PSSD) merupakan gejala tersering setelah stroke. Gangguan tidur setelah stroke meliputi Sleep Disordered Breathing (SDB), insomnia, circadian rhythm sleep disturbance, hipersomnia, parasomnia dan sleep-related movement disorder. Tidur memiliki banyak manfaat, salah satunya adalah restorasi fungsi fisik dan mental, konsolidasi memori dan meningkatkan kemampuan belajar dari seseorang baik secara motorik maupun sensorik. Penelitian lain pun menunjukkan adanya korelasi antara waktu tidur elektrografik dan fungsi kognitif dari pasien stroke pada masa pemulihan. Sebuah penelitian percobaan lain pula mengindikasikan bahwa gangguan tidur dapat meningkatkan ekspresi dari neurocan, yaitu gen yang menghambat pertumbuhan saraf. Gangguan tidur pada pasien stroke dapat menurunkan efisiensi dan efektifitas dari rehabilitasi stroke.
\end{abstract}

Kata kunci: gangguan tidur, luaran klinis, stroke

JNI 2021; $10(1): 47-54$

\section{Sleep Disorders in Acute Phase Stroke Patients}

\begin{abstract}
Stroke is a condition when a person has a sudden neurological deficit caused by a disruption in the blood vessels of the brain. About $21-77 \%$ of stroke patients have sleep disorders that occur after a stroke. The sleep cycle is regulated by the brain and strokes can cause sleep disturbances due to abnormalities that can occur in the brain structures that regulate sleep. Post Stroke Sleep Disoder (PSSD) is the most common symptom after stroke. Sleep disorders after stroke include Sleep Disordered Breathing (SDB), insomnia, circadian rhythm sleep disturbance, hypersomnia, parasomnia and sleep-related movement disorders. Sleep has many benefits, one of which is the restoration of physical and mental functions, the consolidation of memory and improving the learning ability of a person both motorically and sensitively. Other studies have also shown a correlation between electrographic sleep time and cognitive function of stroke patients during recovery. Another experimental study also indicated that sleep disorders can increase the expression of neurocans, which are genes that inhibit nerve growth. Sleep disorders in stroke patients can reduce the efficiency and effectiveness of stroke rehabilitation
\end{abstract}

Key words: outcome, sleep disturbance, stroke

JNI 2021; 10 (1): 47-54 


\section{Pendahuluan}

Stroke adalah suatu kondisi ketika seseorang terkena defisit neurologis secara tiba-tiba yang disebabkan oleh adanya gangguan pada pembuluh darah otak. ${ }^{1}$ Menurut Indonesia's statistical profile yang diterbitkan oleh World Health Organization (WHO) pada tahun 2015, stroke menempati peringkat pertama sebagai penyakit yang paling sering menyebabkan kematian, dengan prevalensi $21,2 \%{ }^{2}$ Sementara itu, menurut hasil Riset Kesehatan Dasar (Riskesdas) 2013, prevalensi stroke di Indonesia sebesar 12\% dan di Jawa Barat sebesar 12,1\%. ${ }^{2}$ Berdasarkan klasifikasi etiologi dari stroke, terdapat dua klasifikasi yaitu stroke iskemik dan stroke perdarahan. Stroke iskemik adalah stroke yang disebabkan oleh penyumbatan pada pembuluh darah arteri serebral. Stroke iskemik sering disebabkan oleh hipertensi, diabetes, hiperkolesterolemia dan merokok, sementara itu stroke perdarahan adalah stroke yang disebabkan oleh pendarahan dan sering disebabkan oleh hipertensi yang terjadi pada pasien berumur 40 70 tahun. Stroke yang paling sering terjadi adalah stroke iskemik. ${ }^{4}$ Siklus tidur diatur oleh otak dan stroke dapat menyebabkan gangguan tidur karena kelainan yang dapat terjadi pada struktur otak yang mengatur tidur.

Post Stroke Sleep Disoder (PSSD) merupakan gejala tersering setelah stroke. Terdapat 21$77 \%$ dari pasien stroke memiliki PSSD. PSSD meliputi sleep disordered breathing (SDB), insomnia, circadian rhythm sleep disturbance, dan hypersomnia. ${ }^{2}$ PSSD dapat didiagnosis dengan questionnaire dan polymsonography (PSG). Menurut penelitian sebelumnya yang menggunakan questionnaire pada pasien stroke iskemik akut, didapatkan $77 \%$ yang mengalami penurunan kualitas tidur, 44,6\% yang memiliki kesulitan untuk tertidur, $24,8 \%$ yang bangun lebih cepat, $11,9 \%$ yang memiliki excessive daytime sleep (EDS), dan 65,35\% yang memiliki SDB. Menurut penelitian lain yang menggunakan questionnaire kepada 277 pasien stroke, 56,7\% memiliki insomnia, 50-71\% memiliki SDB, dan 10-15\% memiliki restless leg syndrome (RLS). ${ }^{5}$ Sementara itu, sebuah penelitian studi klinis menemukan sleep apnea, insomnia dan EDS sebagai tiga gangguan tidur tersering pada pasien stroke. ${ }^{6}$ Penelitian mengenai PSSD masih sedikit walaupun sudah dilakukan banyak penelitian mengenai stroke dan gangguan tidur. Hal ini menjelaskan mengapa data terkait PSSD masih terbatas $^{5}$ dan tidak adanya guideline yang harus dilakukan dokter terkait gangguan tidur dalam rehabilitasi stroke yang diterbitkan oleh UK National Institute of Clinical Excellent (NICE). ${ }^{7}$ Tidur sangat dibutuhkan oleh pasien stroke dalam masa pemulihan karena dapat membantu pasien mendapatkan energi yang cukup untuk menjalani program rehabilitatif dan membantu neuroplastisitas di tingkat synaptic dan network pada otak, terutama pada otak yang berlesi. ${ }^{6-9}$ Tidur juga berperan penting dalam memulihkan kembali kondisi fisik dan mental. ${ }^{6}$ Beberapa penelitian klinis pun menemukan beberapa pasien stroke yang memiliki gangguan tidur mengalami gangguan neuropsikiatris seperti depresi dan kecemasan, dan kognitif (ingatan dan perhatian). ${ }^{10,11}$ Penelitian lain pun menunjukkan adanya korelasi antara waktu tidur elektrografik dan fungsi kognitif dari pasien stroke pada masa pemulihan. ${ }^{12}$ Sebuah penelitian percobaan lain pula mengindikasikan bahwa gangguan tidur dapat meningkatkan ekspresi dari neurocan, yaitu gen yang menghambat pertumbuhan saraf. ${ }^{13}$ Dari penelitian-penelitian mengenai PSSD sebelumnya, telah diakui adanya hubungan antara PSSD dan pemulihan stroke namun penelitian mengenai hubungan lokasi lesi otak stroke dan PSSD masih sedikit. ${ }^{5}$

\section{Tidur}

\section{Definisi Tidur}

Tidur adalah suatu keadaan bawah sadar dimana seseorang masih dapat dibangunkan dengan pemberian rangsang sensorik atau dengan rangsang lainnya. ${ }^{11}$ Tidur juga dapat didefinisikan sebagai suatu kondisi reversibel saat seseorang terlepas dari dan tidak responsif terhadap lingkungansekitarnya. ${ }^{12}$

\section{Mekanisme Tidur}

Siklus sadar dan tidur diregulasi oleh interaksi 
antara sirkuit yang meregulasi kondisi sadar dan kondisi tidur. Kondisi sadar dipengaruhi oleh aktivitas saraf kolinergik pada batang otak, basal forebrain, saraf monoaminergik pada batang otak dan hipotalamus posterior, dan saraf hipokretin pada hipotalamus lateral yang saling berkoordinasi. Transisi dari kondisi bangun menuju tidur melibatkan inhibisi dari beberapa sistem regulasi kesadaran. Inhibisi ini dilakukan oleh grup saraf yang berada pada Ventral Lateral Preoptic (VLPO) dan mammilary posterior nucleus (MnPN) dari hipotalamus. Saraf pada VLPO memiliki neuromodulator inhibitori yaitu, galanin dan neurotransmitter inhibitori yaitu, Gamma Amino Butyric Acid (GABA). Saraf pada MnPN mensintesis GABA. Saraf pada VLPO dan MnPN merupakan sumber projeksi menuju sistem regulasi kesadaran pada hipotalamus posterior dan lateral, dan batang otak rostral. ${ }^{17}$

\section{Sistem Regulasi Kesadaran}

Kesadaran dipengaruhi oleh reticular formation yang berekstensi dari batang otak menuju talamus dan melalui hipotalamus menuju basal forebrain. ${ }^{14}$ Sistem saraf ini meliputi saraf kolinergik pada batang otak dan basal forebrain, saraf monoaminergik pada pons rostral, otak tengah dan hipotalamus posterior dan saraf hipocretin-orexin pada hipotalamus lateral. Saraf pada sistem ini dapat mentransmisikan impuls nonspesifik menuju korteks untuk mengaktivasi kesadaran. Sistem ini mengaktivasi kesadaran melalui dua jalur yaitu, rute dorsal melalui talamus dan rute ventral melalui hipotalamus dan basal forebrain. Salah satu komponen terpenting dari sistem ini adalah saraf kolinergik pada nuklei pedunculopontine (PPT) dan laterodorsal tegmental(LDT) dari batang otak menuju talamus. Saraf kolinergik ini mensintesis acetylcholine, neurotransmiter eksitatori dari sistem saraf pusat. Saraf ini nantinya mengaktivasi saraf talamus yang merupakan komponen terpenting dalam mentransmisikan informasi menuju korteks serebral. Saraf pada PPT dan LDT mengirimkan impuls secara aktif dalam kondisi sadar dan tahap Rapid Eye Movement (REM), yang merupakan tahap yang ditandai dengan adanya aktivasi kortikal namun saraf ini bekerja kurang aktif pada tahap Non Rapid Eye Movement (NREM), ketika aktivitas kortikal rendah. Ada pula grup saraf kolinergik yang bercampur dengan saraf nonkolinergik pada basal forebrain yang berprojeksi sampai korteks, hippocampus dan talamus. Saraf ini sangat aktif dalam aktivasi korteks saat sadar dan pada tahap REM. Saraf lain yang berperan pula dalam mengaktivasi kesadaran yaitu, saraf monoaminergik pada noradrenergic locus coeruleus (LC), median raphe nuclei, ${ }^{15}$ saraf dopaminergik pada ventral periaqueductal, dan saraf histaminergik tubermammilary pada tuberomammilary nucleus (TMN). Grup saraf monoaminergik ini berprojeksi sampai intralaminar dan tengah dari nuklei talamus, juga innervasi hipotalamus lateral, basal forebrain, dan korteks serebral, namun berbeda dengan grup saraf lainnya, grup saraf monoaminergik ini berkarakteristik sebagai "REM-off" karena aktivitasnya yang kurang aktif saat kondisi tidur baik itu pada tahap NREM ataupun REM. Input menuju cerebral cortex juga dibantu oleh saraf peptidergik pada hipotalamus lateral yang memiliki melanin-concentrating hormone $(\mathrm{MCH})$ atau orexin dan saraf kolinergik atau GABAergik pada basal forebrain. Saraf $\mathrm{MCH}$ berprojeksi sampai tengah dari nuklei hipotalamik, area preoptik lateral dan neokorteks. Saraf orexin pada hipotalamus lateral ini sangat aktif pada kondisi sadar sedangkan saraf $\mathrm{MCH}$ aktif saat tahap REM. ${ }^{10}$

\section{Sistem Regulasi Tidur pada Preoptik Hipotalamus}

Transisi dari kondisi sadar menuju tidur dimediasi oleh kombinasi antara faktor homeostasis dan faktor intrinsik sirkadian. Faktor sirkadian meliputi input dari nukleus suprakiasmatik pada hipotalamus anterior dan transkripsi dan translasi gen Cry1, Cry2, Per1, Per2, Bmal, dan Clock. Faktor homeostasis meliputi substansi regulator tidur seperti adenosin yang memiliki banyak reseptor pada talamus dan basal forebrain, growth hormone-releasing hormone (GHRH), tumor necrosis factor alpha (TNF-alpha), dan interleukin 1 beta (IL-1beta) yang memiliki banyak reseptor pada hipotalamus. Faktor homeostasis berasosiasi dengan beban 16 kerja saraf saat kondisi bangun, sementara faktor intrinsik sirkadian berasosiasi dengan waktu optimal yang dibutuhkan untuk 
transisi sadar menuju tidur dan berkaitan dengan lingkungan fisik. ${ }^{18}$ Sebuah hipotesis menyatakan bahwa kebutuhan tidur akan meningkat saat waktu kondisi sadar meningkat. Hal ini disebabkan oleh adanya peningkatan aktivitas saraf yang membutuhkan konsumsi energi yang meningkat. Peningkatan konsumsi energi akan meningkatkan produksi adenosine ekstraseluler pada otak. Adenosin akan menurunkan aktivitas saraf pada basal forebrain melalui reseptor $\mathrm{A} 1$ dan $\mathrm{A} 2 \mathrm{~A}$, dan dapat mempromosikan tidur melalui efek eksitatorinya pada sistem saraf yang meregulasi tidur. Hal ini akan menurunkan kebutuhan energi pada otak selama tidur. Penurunan kebutuhan energi pada otak ini akan menyebabkan terjadinya peningkatan adenosine triphosphate (ATP) sehingga konsentrasi adenosin intraseluler pun akan menurun sehingga dapat memulihkan kembali aliran darah dan aktivitas elektrik yang akan mengembalikan kesadaran seseorang setelah tidur. ${ }^{18}$ Sistem saraf yang meregulasi tidur terletak pada VLPO dan MnPN. Saraf pada VLPO dan MnPN bekerja sangat aktif pada tahap NREM dan REM dibanding pada saat kondisi bangun. Saraf pada VLPO dan MnPN juga mengekspresikan lebih banyak Fos-protein dengan glutamic acid decarboxylase (GAD), yang merupakan marker dari sel GABAergik. Aktivasi saraf GABAergik pada VLPO dan MnPN adalah komponen utama yang menekan aktivitas saraf monoaminergik, kolinergik, dan orexin saat tidur. ${ }^{17}$ Di sisi lain, VLPO dan MnPN memiliki fungsi yang berbeda pada saat kondisi tidur. Sebuah studi eksperimental menunjukkan bahwa saraf GABAergik pada VLPO akan meningkatkan waktu tidur dalam merespons waktu kondisi bangun, sementara saraf GABAergik pada MnPN akan meningkatkan intensitas tidur saat teraktivasi. Hal ini dapat disimpulkan bahwa respons homeostasis terhadap waktu kondisi bangun meliputi peningkatan waktu tidur, peningkatan kedalaman tidur, dan konsolidasi tidur yang bergantung pada aktivasi MnPN dan VLPO secara terintegrasi. ${ }^{10}$

\section{Tahap Tidur}

Tidur terdiri atas beberapa tahap. Tahap ini ditentukan berdasarkan karakteristik dari elektroensefalografi (EEG). Tahap tidur meliputi
NREM dan REM. NREM terdiri atas 4 tahap. Tahap I ditandai dengan adanya perubahan spektrum EEG ke arah bawah dan peningkatan gelombang kortikal. Tahap I akan berprogress menjadi tahap II. Tahap II ditandai dengan adanya penurunan frekuensi gelombang EEG, peningkatan amplitudo gelombang EEG, dan peningkatan frekuensi dari klaster spindle (sleep spindles) secara intermiten. Sleep spindles merupakan sebuah aktivitas periodik dalam skala 10-12 Hz selama 1-2 detik karena adanya interaksi antara saraf talamik dan kortikal. Tahap II diikuti dengan tahap III yang ditandai dengan adanya penurunan sleep spindles dan peningkatan dari amplitudo gelombang berfrekuensi rendah. Tahap III akan dilanjutkan oleh tahap IV yang ditandai dengan rendahnya frekuensi gelombang EEG sebesar $1-4 \mathrm{~Hz}$ dan 18 peningkatan amplitudo dari fluktuasi gelombang EEG (gelombang delta). NREM terjadi selama satu jam. Setelah otak melalui tahap NREM, maka aktivitas otak pada EEG akan kembali seperti kondisi bangun. Tahap ini disebut juga taham REM. Otak akan memasuki tahap REM selama kurang lebih 10 menit dan nantinya dilanjutkan dengan memasuki kembali tahap NREM. Hal ini terjadi dalam siklus sampai tahap REM terjadi sekitar empat periode dengan durasinya yang semakin menurun. Jumlah waktu tahap REM akan menurun seiring bertambahnya usia. Pada saat kelahiran, durasi waktu REM adalah delapan jam. Pada umur 10 tahun, durasi waktu REM adalah dua jam. Pada umur 70 tahun, durasi waktu REM adalah 45 menit. ${ }^{15}$ Di sisi lain, beberapa studi menunjukkan bahwa tahap NREM dan REM berperan penting dalam proses belajar dan konsolidasi memori. Tahap REM berperan penting dapat memproses memori dan ilmu yang baru dipelajari secara sensorik dan motorik. Tahap NREM berperan dalam homeostasis tidur dan memiliki pengaruh terhadap fungsi kognitif. Studi lain membuktikan bahwa gelombang lambat pada tahap NREM dapat meningkatkan plastisitas saraf. $^{12}$

\section{Gangguan Tidur pada Pasien Stroke}

Gangguan tidur dapat menjadi faktor resiko dari stroke ataupun manifestasi klinis dari stroke. ${ }^{17} \mathrm{Ada}$ $21-77 \%$ dari pasien stroke memiliki gangguan 
tidur yang terjadi setelah stroke. Gangguan tidur setelah stroke meliputi Sleep Disordered Breathing (SDB), insomnia, circadian rhythm sleep disturbance, hipersomnia, parasomnia dan sleep-related movement disorder. ${ }^{5}$ Sebuah studi klinis menemukan tiga gangguan tidur tersering pada pasien stroke, yaitu sleep apnea, excessive daytime sleepiness (EDS) dan insomnia. ${ }^{6} \mathrm{SDB}$ adalah suatu penyakit yang meliputi masalah pernapasan dan ventilasi saat tidur. Masalah pernapasan dan ventilasi saat tidur tersebut dapat berupa habitual snoring, obstructive sleep apnea (OSA), dan central sleep apnea (CSA). Gejala tersering yang terjadi pada pasien dengan

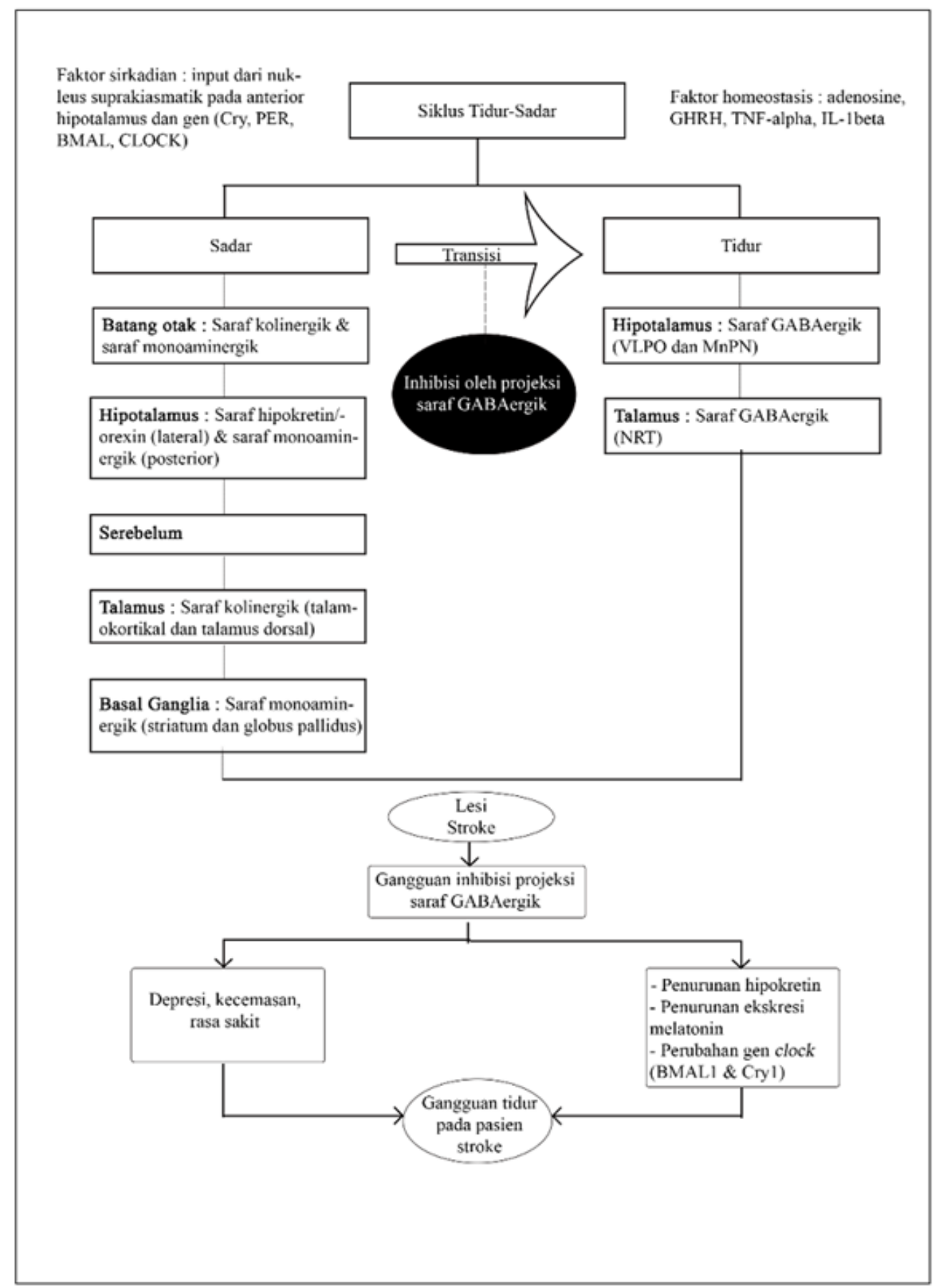

Gambar 1. Patofisiologi Terjadinya Gangguan Tidur pada Pasien Stroke ${ }^{2}$ 
SDB adalah daytime sleepiness. Salah satu metode untuk mendiagnosisnya adalah dengan menggunakan Epworth Sleepiness Scale (ESS). Ada pula metode lain yaitu, dengan menggunakan Berlin Questionnaire (BQ). ${ }^{17}$ Insomnia adalah suatu penyakit yang berkarakteristik sulit tidur, sulit bertahan tidur, bangun tidur lebih dini pada pagi hari, dan tidak memiliki tidur yang restoratif walaupun memiliki banyak waktu untuk tidur. ${ }^{17}$ Insomnia dapat didiagnosis dengan menggunakan ESS, diari tidur, polisomnogram, dan aktigrafi. ${ }^{10}$ Ketika seseorang terkena stroke, maka dapat terjadi perubahan neurokimia pada otaknya, seperti terjadinya perubahan biomarker. Perubahan biomarker yang dapat berkontribusi dalam terjadinya gangguan tidur adalah perubahan signaling dari neurotransmitter seperti hipokretin, perubahan transkripsi dan translasi gen 23 Bmall \& Cry1, dan penurunan ekskresi dari melatonin. Ada pula faktor lainnya yang berkontribusi dalam terjadinya gangguan tidur pada stroke yaitu depresi, rasa sakit, kecemasan, dan lingkungan rumah sakit. ${ }^{18}$

\section{Pendekatan Diagnosis Gangguan Tidur pada Pasien Stroke}

Gold standard dari diagnosis gangguan tidur adalah polisomnografi. Polisomnografi meliputi EEG, electromyografi (EMG), dan electrookulografi (EOG). Polisomnografi dapat mendiagnosis gangguan tidur organik seperti sleep disorder breathing (SDB) dan periodic limb movement disorder, namun sebuah studi klinis mengatakan bahwa penggunaan polisomnografi pada pasien stroke tidak mungkin dilakukan pada pasien stroke akut. Hal ini menyebabkan penggunaan kuesioner pada pasien stroke untuk mendiagnosis gangguan tidur lebih sering digunakan. ${ }^{18}$ Di sisi lain, pada beberapa penelitian sebelumnya, peneliti menggunakan kuesioner dalam menemukan gangguan tidur pada pasien stroke. Kuesioner yang sering digunakan di antaranya adalah pittsburgh sleep quality index (PSQI), insomnia severity iIndex (ISI), Berlin Questionarre (BQ), dan sleep obstructive apnea score optimized for stroke (SOS). PSQI dapat mengidentifikasi kualitas tidur secara umum. ISI dapat mengidentifikasi kesulitan tidur pada seseorang, kepuasan seorang individu terhadap tidurnya, dan seberapa mengganggunya tidur seseorang dengan fungsi kesehariannya. ESS dapat mengidentifikasi excessive daytime sleepiness. BQ meliputi pertanyaan mengenai keparahan mendengkur saat tidur, excessive daytime sleepiness, riwayat tekanan darah tinggi dan obesitas. SOS memiliki akurasi yang 24 lebih besar daripada BQ dan ESS, dan dapat digunakan untuk melakukan screening sleep apnea pada pasien stroke. ${ }^{5}$

\section{Pittsburgh Sleep Quality Index (PSQI)}

PSQI digunakan untuk menilai gangguan tidur dan kebiasaan tidur seseorang hanya dalam waktu satu bulan sebelumnya. PSQI terdiri atas 19 item yang dapat menilai kualitas tidur secara subyektif, waktu yang diperlukan untuk memulai tidur, durasi tidur, efisiensi tidur, gangguan tidur, penggunaan obat dalam membantu tidur, dan gangguan tidur yang sering terjadi pada siang hari. Ada empat skala dari masing-masing pertanyaan. Hasil dari seluruh pertanyaan akan dijumlahkan dan diinterpretasikan. Hasil dengan 0 sampai 5 menunjukkan seseorang tidak memiliki gangguan tidur (good sleepers), sementara hasil dengan lebih dari 5 menunjukkan seseorang memiliki gangguan tidur (bad sleepers). ${ }^{13}$ PSQI telah diuji validitas dan reliabilitasnya untuk menilai gangguan tidur pada populasi pasien yang telah memiliki lesi otak akut. ${ }^{14}$ PSQI juga telah banyak digunakan oleh peneliti untuk mengidentifikasi gangguan tidur pada pasien stroke. ${ }^{5,6,8}$ PSQI memiliki spesifisitas sebesar $86,5 \%$ dan sensitifitas sebesar $89,6 \%{ }^{15}$

\section{Hubungan Lokasi Lesi Otak dengan Gangguan Tidur pada Pasien Stroke}

Beberapa penelitian sebelumnya mengenai hubungan lokasi lesi otak dengan gangguan tidur pada pasien stroke baru hanya dilakukan pada beberapa gangguan tidur spesifik seperti rest less leg syndrome (RLS), insomnia dan REM sleep behavior disorder (RDB). Sebuah studi kasus mengenai RLS menemukan bahwa lesi subkortikal seperti traktus piramidal dan axis basal ganglia-batang otak, yang berperan dalam fungsi motorik dan siklus tidur, dapat menyebabkan terjadinya gejala RLS. ${ }^{16}$ Sebuah studi observatif 
mengenai insomnia menemukan bahwa lesi pada dorsomedial frontal kiri berasosiasi dengan insomnia. ${ }^{17}$ Sebuah studi eksperimental mengenai RDB menemukan bahwa lesi pada pons berasosiasi dengan RDB. ${ }^{18}$ Sebuah studi klinis yang meneliti hubungan gangguan tidur dengan stroke yang juga mempertimbangkan adanya hubungan dengan lokasi lesi otak, namun studi klinis tersebut menemukan tidak adanya hubungan yang signifikan antara lokasi lesi otak dengan gangguan tidur. ${ }^{12}$

\section{Manfaat Tidur pada Pasien Stroke Fase} Akut

Tidur memiliki banyak manfaat, salah satunya adalah restorasi fungsi fisik dan mental, konsolidasi memori dan meningkatkan kemampuan belajar dari seseorang baik secara motorik maupun sensorik. Konsolidasi memori adalah transformasi memori dari status labil menjadi status yang permanen di dalam otak. ${ }^{6}$ Kemampuan yang dipelajari seseorang dapat berupa dua jenis yaitu, kemampuan implisit dan kemampuan eksplisit. Ketika seseorang dengan sadar mempelajari suatu kemampuan, maka disebut kemampuan eksplisit. Sedangkan ketika seseorang dengan tidak sadar mempelajari suatu kemampuan, maka disebut kemampuan implisit. Proses belajar kemampuan eksplisit bergantung pada tidur, sedangkan proses belajar kemampuan implisit bergantung pada waktu. Hal ini berbeda dengan pasien stroke. Sebuah studi klinis membuktikan bahwa proses belajar kemampuan implisit pada pasien stroke juga dipengaruhi oleh tidur. Studi tersebut menunjukkan bahwa pasien stroke yang tidur di antara sesi rehabilitasi mengalami perkembangan yang signifikan dibanding pasien stroke yang tidak tidur di antara sesi rehabilitasi, maka dari itu gangguan tidur pada pasien stroke dapat menurunkan efisiensi dan efektifitas dari rehabilitasi stroke. ${ }^{6}$

\section{Simpulan}

Gangguan tidur dapat menjadi faktor resiko dari stroke ataupun manifestasi klinis dari stroke. Gangguan tidur setelah stroke meliputi SDB, insomnia, circadian rhythm sleep disturbance, hipersomnia, parasomnia dan sleep-related movement disorder. PSQI telah diuji validitas dan reliabilitasnya untuk menilai gangguan tidur pada populasi pasien yang telah memiliki lesi otak akut. Gangguan tidur pada pasien stroke dapat menurunkan efisiensi dan efektifitas dari rehabilitasi stroke.

\section{Daftar Pustaka}

1. BerkowitzAL.Preface. In:ClinicalNeurology and Neuroanatomy: A Localization-Based Approach [Internet]. New York, NY: McGraw-Hill Education; 2016. Available from: http://neurology.mhmedical.com/ content.aspx?aid $=1137959269$

2. Kim KT, Moon HJ, Yang JG, Sohn SI, Hong $\mathrm{JH}$, Cho YW. The prevalence and clinical significance of sleep disorders in acute ischemic stroke patients - a questionnaire study. Sleep and Breathing. 2017 Jan 7:1-7.

3. Joa K-L, Kim W-H, Choi H-Y, Park C-H, Kim E-S, Lee S-J, et al. The effect of sleep disturbances on the functional recovery of rehabilitation inpatients following mild and moderate stroke. Am J Phys Med Rehabil. 2017 Oct;96(10):734-40.

4. Kim J, Kim Y, Yang KI, Kim D-E, Kim SA. The relationship between sleep disturbance and functional status in mild stroke patients. Ann Rehabil Med. 2015 Aug;39(4):545-52.

5. Zunzunegui C, Gao B, Cam E, Hodor A, Bassetti CL. Sleep disturbance impairs stroke recovery in the rat. Sleep. 2011 Sep;34(9):1261-69.

6. Leppävuori A, Pohjasvaara T, Vataja R, Kaste M, Erkinjuntti T. Insomnia in ischemic stroke patients. Cerebrovasc Dis [Internet]. 2002;14(2):90-7.

7. Hermann DM, Bassetti CL. Sleep-related breathing and sleep-wake disturbances in ischemic stroke. Neurology. 2009 Oct;73(16):1313-22. 
8. Vetrivelan R, Qiu MH, Chang C, Lu J. Role of basal ganglia in sleep-wake 41 regulation: neural circuitry and clinical significance. Frontiers in neuroanatomy. 2010 Nov $23 ; 4: 145$.

9. Baglioni C, Nissen C, Schweinoch A, Riemann D, Spiegelhalder K, BergerM, et al. Polysomnographic characteristics of sleep in stroke: a systematic review and metaanalysis. PLoS One. 2016;11(3):e0148496.

10. Buysse DJ, Reynolds CF, Monk TH, Berman SR, Kupfer DJ. The Pittsburgh Sleep Quality Index: a new instrument for psychiatric practice and research.Psychiatry research. 1989 May 1;28(2):193-213.

11. Schutte-Rodin S, Broch L, Buysse D, Dorsey C, Sateia M. Clinical guideline for the evaluation and management of chronic insomnia in adults. J Clin sleep Med JCSM Off Publ Am Acad Sleep Med. 2008;4(5):487.

12. Camilo MR, Sander HH, Eckeli AL, Fernandes RMF, dos Santos-Pontelli TEG, Leite JP, et al. SOS score: an optimized score to screen acute stroke patients for obstructive sleep apnea. Sleep Med. 2014;15(9):1021-4.

13. Johns MW. A new method for measuring daytime sleepiness: the Epworth sleepiness scale. Sleep. 1991 Nov 1;14(6):540-5.

14. Lee SJ, Kim JS, Song IU, An JY, Kim YI, Lee KS. Poststroke restless legs syndrome and lesion location: anatomical considerations. Movement Disorders. 2009 Jan 15;24(1):77_84.

15. Koenigs M, Holliday J, Solomon J, Grafman J. Left dorsomedial frontal brain damage is associated with insomnia. Journal of Neuroscience. 2010 Nov 24;30(47):16041-3.

16. Iranzo A, Aparicio J. A lesson from anatomy: focal brain lesions causing REM sleep behavior disorder. Sleep medicine. 2009 Jan 1;10(1):9-12.

17. Sterr A, Herron K, Dijk DJ, Ellis J. Time to wake-up: sleep problems and daytime sleepiness in long-term stroke survivors. Brain Injury. 1008 Jan 1;22(7-8):575-9.

18. Pearce SC, Stolwyk RJ, New PW, Anderson C. Sleep disturbance and deficits of sustained attention following stroke. Journal of clinical and experimental neuropsychology. 2016 Jan 2;38(1):1-7. 